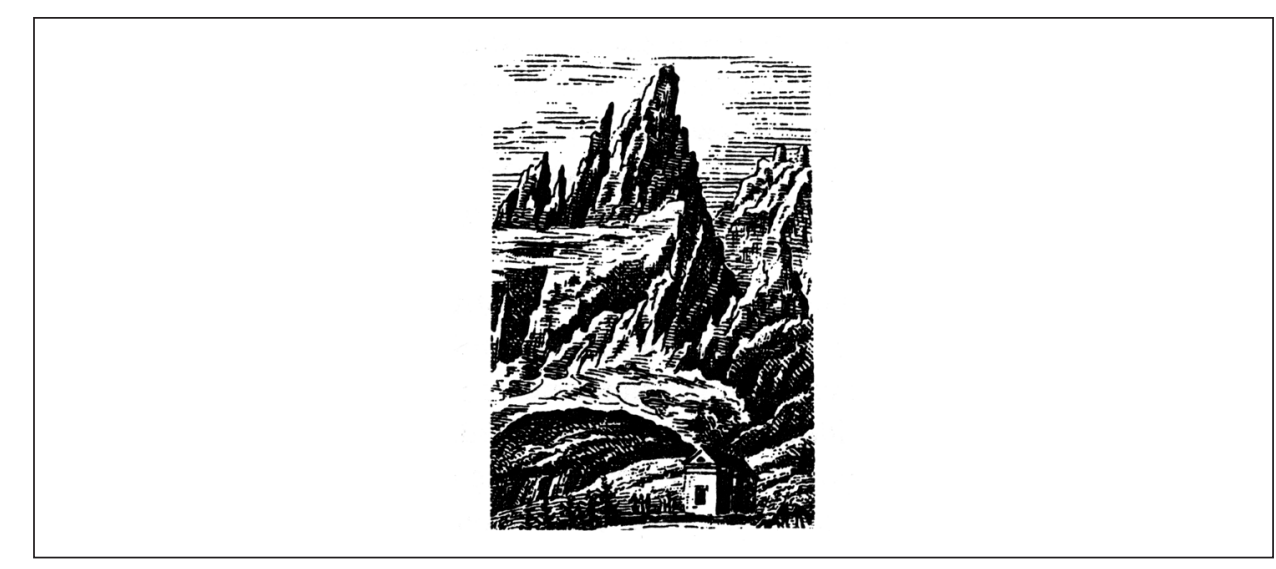

Ewa Grzęda

Wroctaw

ewagrzeda@02.pl

Monika Witt

Nysa

monika.witt@pwsz.nysa.pl

DOI: $10.19195 / 2084-4107.10 .19$

\title{
Kilka uwag o księgach pamiątkowych ze schroniska nad Śnieżnymi Kotłami z przełomu XIX i XX w. / Einige Bemerkungen über die Fremdenbücher der Schneegrubenbaude an der Jahrhundertwende
}

Słowa-klucze: Karkonosze, Śnieżka, Śnieżne Kotły, księga pamiątkowa, turystyka, schronisko górskie

Wśród przechowywanych w zbiorach specjalnych Biblioteki Uniwersyteckiej we Wrocławiu ksiąg pamiątkowych z obszaru Karkonoszy na szczególną uwagę zasługują dwa obszerne korpusy zawierające w sumie dwadzieścia jeden tomów gęsto zapełnionych wielojęzycznymi wpisami i osobliwymi rysunkami. 


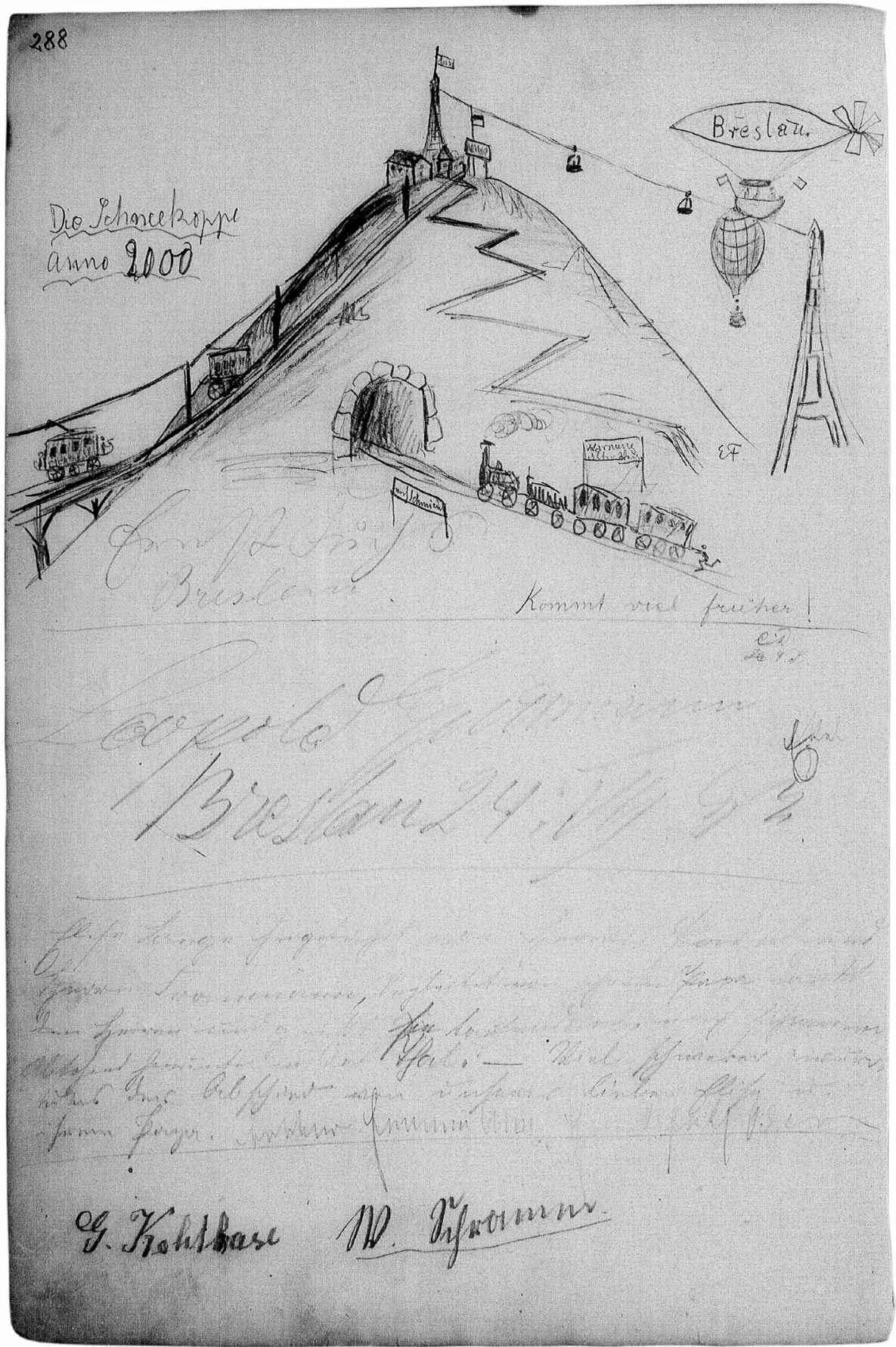

14. Wizja Śnieżki w 2000 r., rysunek Fremdenbuch der Schneegruben-Baude 1892: Księga odwiedzin schroniska pod Śnieżnymi Kotłami [sic!] od 28 V 1892 r. do 25 VII 1901 r.; BU Wrocław, Akc 1950 KN 1093/10, mf. 4523 


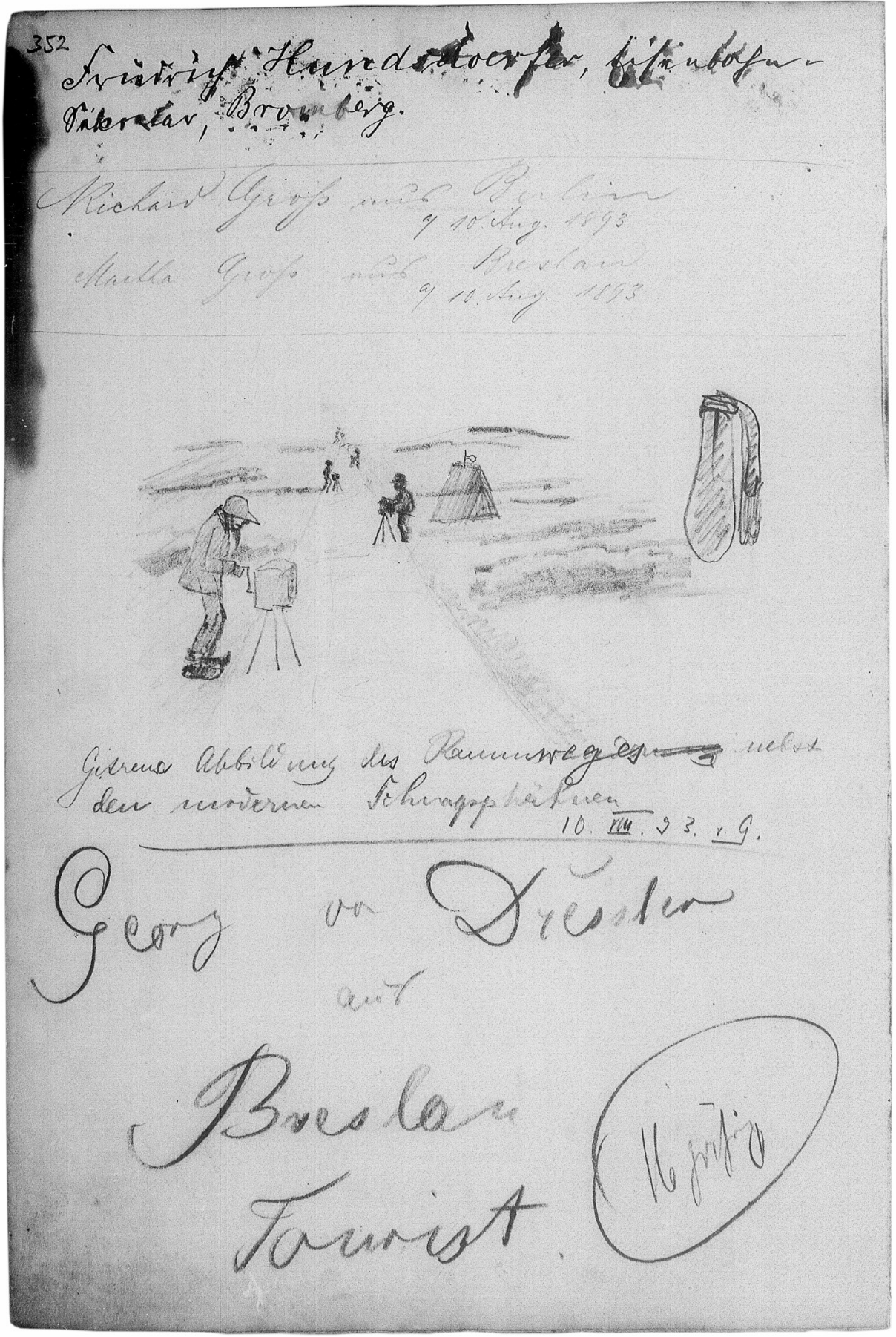

15. Kataryniarze na szlakach pod Śnieżką, rysunek Fremdenbuch der Schneegruben-Baude 1892: Księga odwiedzin schroniska pod Śnieżnymi Kotłami [sic!] od 28 V 1892 r. do 25 VII 1901 r.; BU Wrocław: Akc 1950 KN 1093/10, mf. 4523 
Pierwszy zespół ksiąg - najcenniejszy z zachowanych — tworzą tzw. Koppenbuchy obejmujące wpisy z lat (1710-1840), drugi obszerny, i jak się wydaje niemniej interesujący zbiór obejmujący (dziesięć tomów), stanowią księgi ze schroniska nad Śnieżnymi Kotłami (Fremdenbuch der Schneegrubebaude), wystawiane w starym i nowym schronisku w latach 1890-1914.

Te osobliwe zbiory dokumentów unaoczniających rozwój i przemiany ruchu turystycznego w Karkonoszach są cennym źródłem wiedzy z zakresu funkcji i znaczenia gór, zarówno w kulturze, jak i świadomości społecznej — nie tylko w perspektywie regionalnej (śląskiej), lecz także o wiele szerszej. To właśnie dzięki wielojęzycznym wpisom umieszczanym przez pielgrzymów, a następnie turystów w tzw. księgach Śnieżki wystawianych od schyłku XVII w. (pierwsze znane wpisy datowane są na rok 1696) ${ }^{1}$ w schronisku pod Śnieżką i w siedemnastowiecznej kaplicy na szczycie można zrekonstruować w przybliżeniu socjologiczny i narodowo-etniczny skład publiczności odwiedzającej Karkonosze od schyłku XVII w.

Znaczenie dokumentacyjne, ale w pewnym zakresie także osobliwą wartość literacką i artystyczną gamy wpisów znajdujących się w owych księgach pamiątkowych potwierdza fakt, że pierwsze ich drukowane ekscerpty pojawiły się już w XVIII w. Interesujący wybór został wydrukowany w 1737 r. w drukarni Krahna w Jeleniej Górze pod rozbudowanym - typowym dla konwencji barokowej - tytułem Vergnügte und unvergnügte Reisen auf das Weltberufene RiesenGebirge welche von 1696 bis 1737. Theils daselbst der Allerhöchsten zu preisen, theils die erstaunenden Wunder der Welt zu betrachten, theils sich eine Gemüthvergnügung oder Leibesbewegung zu machen, theils den beruffenen Riebezahl auszukundschaften, von allerhand Liebhabern angestellt worden sind. Die sich den zu einen beständigen Andenken in die daselbst befindlichen Schneekoppen - Bücher Namentlich und meistens mit beyläufigen merkwürdigen Gedanken in gebundener und ugebundener Rede eingeschneben haben (Hirschberg 1736) ${ }^{2}$ (Przyjemne i nieprzyjemne wyprawy na sławne $w$ świecie ślaskie Karkonosze od 1696 do 1737. Przez różnych amatorów bądź dla Najwyższemu tamże czci oddania, badź dla zdumiewajacym cudom natury przypatrzenia się, badź dla duszy rozweselenia albo ciata rozruszenia oraz Rzepióra sławnego wytropienia przedsięwzięte. Którzy się na trwała pamiatkę w tamże istniejace księgi Śnieżki, imiennie i przeważnie pochlebnymi, osobliwymi myśli, mowa wiazana i niewiazana wpisali... Wraz z przemowa o: cudach, pięknie, doskonałości oraz przyrodzonych cechach tych gór ${ }^{3}$.

Kolejne drukowane wypisy z ksiąg Śnieżki ukazały się pod koniec XVIII w. Jak podaje Ryszard Kincel:

1 R. Kincel, Sarmaci na Śnieżce, Wrocław 1973, s. 7.

2 Podaję za: J. Kolbuszewski, Vergnügte und Unvergnügte Reisen auf das weltberufene schlesische Riesengebirge, [w:] Daß eine Nation die ander verstechen möge, Festschrift für Marian Szyrocki zu seinem 60. Geburtstag, red. N. Honsza, H.G. Roloff, Amsterdam 1988, s. 438.

3 Przekład tytułu podaję za: R. Kincel, op. cit., s. 7. 
Pod koniec XVIII stulecia ukazało się [...] wydawnictwo zawierające wyciąg z ksiąg Śnieżki od 1774 do 1789 r. Podobny ekscerpt opublikowano jeszcze w 1769 r. Ale równocześnie pęczniały od turystycznych wpisów coraz to nowe roczniki ksiąg pamiątkowych. Prawdziwa moda na nie nastała dopiero w pierwszej połowie XIX w. Kiedy natomiast w drugiej połowie tegoż stulecia poczęły wychodzić ze zwyczaju i gdy krajoznawcy nimi zainteresowani zaczęli spoglądać wstecz, nie potrafiono ustalić, co się z nimi stało. Nigdzie po prostu nie było oryginałów ksiąg udostępnianych niegdyś turystom w schronisku pod Śnieżką oraz w kaplicy na tej górze.

Pod koniec minionego stulecia znaleziono jednakże dwa woluminy oryginalnych ksiąg Śnieżki. Obie księgi zostały odkryte w Bolesławcu i trafiły potem do zbiorów Muzeum w Jeleniej Górze. Pierwsza obejmowała lata 1800-1806, druga 1812-1819. Charakterystyka obu ksiąg pamiątkowych, podnosząca ich duże walory jako źródła do dziejów turystyki górskiej, opublikowana została w $1886 \mathrm{r}$. w piśmie krajoznawczym, w przekładzie polskim noszącym tytuł „Wędrownik w Karkonoszach ${ }^{4}$ (oryginalny tytuł pisma to „Der Wanderer im Riesengebirge” 1881-1943).

Po drugiej wojnie światowej okazało się, że we wrocławskiej Bibliotece Uniwersyteckiej ocalał bardzo obszerny zespół owych ksiąg. Zaskakujący jest fakt, iż pomimo niezwykłej wartości dokumentacyjnej zachowanych $\mathrm{w}$ dobrym stanie zespołów ksiąg pamiątkowych z karkonoskich schronisk, w drugiej połowie $\mathrm{XX}$ w. budziły one niewielkie zainteresowanie badaczy i zostały skomentowane tylko w pewnym zakresie. Być może jakąś przeszkodą w prowadzeniu badań nad tym niezwykle interesującym zespołem dokumentów były niefortunne uwarunkowania polityczne i ideologiczne. W tym kontekście zwrócić trzeba uwagę na pionierskie badania Jacka Kolbuszewskiego, dotyczące nie tylko wpisów polskojęzycznych, na czym swoją uwagę skupiał Ryszard Kincel — autor cennej pracy Sarmaci na Śnieżce (1973), ale także niemieckojęzycznych i czeskich ${ }^{5}$ oraz na przyczynek Uwe-K. Ketelsena, dotyczący wpisów niemieckojęzycznych ${ }^{6}$.

Co istotne, badaczy zajmujących się do tej pory wpisami z ksiąg Śnieżki interesował przede wszystkim zespół najstarszych Koppenbuchów, rzadziej sięgali oni po księgi pamiątkowe ze schroniska nad Śnieżnymi Kotłami z przełomu XIX i XX w.

4 Ibidem, s. 8.

5 J. Kolbuszewski, Czeskie wiersze w księgach pamiątkowych Śnieżki, „Sbornik Praci Filozoficke Fakulty Brnenske Univerzity Studia Minora Facultatis Philosophicae Universitatis Brunensis" 32, 1985, s. 131.

${ }^{6}$ U.K. Ketelsen, Ein Einbruch der Ungelehrten in die Domäne der Schrift. Touristische Konstituierung von Natur im „Koppen-Buch” des Grafen Schaffgotsch, [w:] Aufklärung in Schlesien im europäischen Spannungsfeld Traditionen-Diskurse-Wirkungen, red. W. Kunicki, Wrocław 1996, s. 111-131. 
Tymczasem korpus ksiąg ze schroniska nad Śnieżnymi Kotłami wydaje się szczególnie interesujący, gdyż stanowi ważny dokument stylu podróżowania i ewolucji procesu percypowania przestrzeni górskiej na przełomie XIX i XX w., pozwalający na prześledzenie i zrekonstruowanie bardzo spektakularnych zmian zachodzących w świadomości społecznej i kulturowej turystów odwiedzających w tym czasie Karkonosze. Jak się wydaje, są to zjawiska i fakty uniwersalne, porównywalne ze zjawiskami w dużej skali europejskiej.

Już wstępna analiza początkowych tomów ksiąg ze schroniska nad Śnieżnymi Kotłami wskazuje na wyraźnie rysujące się w tym okresie początki turystyki masowej ${ }^{7}$ - turystyki, która podlega procesowi gwałtownej demokratyzacji i nosi wyraźne piętno nowoczesności.

Interesujące nas księgi pamiątkowe ze schroniska nad Śnieżnymi Kotłami w Karkonoszach należą do gatunku intensywnie rozwijającego się w pierwszej połowie XIX w. i nadal funkcjonującego na przełomie XIX i XX w., choć biorąc pod uwagę siedemnastowieczny rodowód ksiąg szczytowych Śnieżki, można nawet $\mathrm{w}$ pewnym sensie doszukiwać się ich genetycznego pokrewieństwa z powstałym w tym samym wieku modelem (silva rerum). Swojego czasu zwrócił na to uwagę Jacek Kolbuszewski ${ }^{8}$.

W każdym razie nie należy koncepcji ksiąg Śnieżki i ksiąg ze schroniska nad Śnieżnymi Kotłami mylić z dzisiejszymi schroniskowymi książkami wyjść, w których odnotowuje się plany wspinaczkowe czy turystyczne, godziny wyjścia oraz planowanego rzeczywistego powrotu do schroniska, a które służą bezpieczeństwu i po części zewnętrznej dokumentacji.

Funkcją ksiąg pamiątkowych jest upamiętnienie pobytu w schronisku czy też w okolicznych górach. Tak więc należy szukać tu raczej ich bezpośredniego pokrewieństwa $\mathrm{z}$ księgami pamiątkowymi wykładanymi $\mathrm{w}$ atrakcyjnych turystycznie miejscach, takich jak np. zabytkowe budowle, domy zdrojowe, izby pamięci itp., tudzież z księgami szczytowymi, które służą w pierwszym rzędzie udokumentowaniu swojej bytności na (często trudno dostępnym) wierzchołku.

Wydaje się, że u podstaw tych gatunków leży chęć zaznaczenia swojej obecności w wyjątkowym, z punktu widzenia autora wpisu, miejscu. W tym kontekście moglibyśmy szukać początków gatunku także w inskrypcjach naskalnych takich jak ta, o której powstaniu pisze Jakob Buchholtz w swojej relacji o odbytej w 1708 r. wraz ze starszym bratem Georgiem (Jerzy) wycieczce do Łomnickiego Stawu w Tatrach. Tam Georg „w przypływie lekkomyślności” dopłynął do środka jeziora i na wystającym zeń kamieniu „wyrył nożem swe nazwisko" 9 . O ile inskrypcje takie powstawały raczej w spontaniczny sposób, o tyle „puszki

7 Za datę inicjującą zjawisko turystyki masowej uznaje się rok 1841, a za jej twórcę uznaje Brytyjczyka Thomasa Cooka, który 5 lipca 1841 wynajął pociąg i zorganizował wycieczkę na zjazd trzeźwości z Leicester do Loughborough i z powrotem.

8 J. Kolbuszewski, Vergnügte und Unvergnügte Reisen auf das weltberufene schlesische Riesengebirge..., s. 437.

9 J. Szaflarski, Poznanie Tatr, Warszawa 1972, s. 129.

Góry — Literatura — Kultura 10, 2016

(C) for this edition by CNS 
szczytowe", w których pozostawiano najpierw odręcznie zanotowane nazwiska, a potem bilety wizytowe, wymagały planowania, wpis do nich był punktem w planie wycieczki. Czytamy o tym już w powieści szelmowskiej Węierski bądź Dacki Simplicissimus, która ukazała się w roku $1683^{10}$, sama zaś opisywana wycieczka miała miejsce około 1650 r. i prowadziła najprawdopodobniej na Kieżmarski Szczyt ${ }^{11}$. Bohater powieści, będący w tym czasie studentem liceum kieżmarskiego, opowiada o pobycie na szczycie:

Przewodnik pokazał nam pod zwisającą, dziko poszarpaną skałą nagromadzony stos kamieni, pod którym leżały blaszane skrzyneczki, a w nich pergaminy z zapisanymi imionami. Żal nam się zrobiło, żeśmy tego ze sobą na pamiątkę nie wzięli, aż tu przewodnik rzecze „Mam pergamin i blaszaną skrzyneczkę. Co dostanę, gdy wam to dam, a także inkaust i pióro?". Obiecaliśmy jednego florena za to, a wówczas każdy zapisał swoje imię, wiek, miejsce, w którym się urodził, rok i dzień, włożyliśmy pergamin do skrzyneczki i naznosili kamieni jeszcze więcej, niż było ${ }^{12}$.

Zwyczaj pozostawiania takiej informacji o zdobyciu szczytu nabrał szczególnego znaczenia w okresie eksploracji Alp i innych masywów górskich. W środowisku taternickim znany był spór Romana Kordysa z Karolem Englischem dotyczący między innymi pierwszego wejścia na Zachodni Szczyt Wideł. Spór rozstrzygnęło oświadczenie Miklosa Szontagha mł. o znalezionym na tymże szczycie bilecie wizytowym Englischa ${ }^{13}$. Dziś w rozstrzyganiu takich sporów pomagają zdjęcia. Coraz bardziej znany jest system dygitalny: smartfon lub GPS wyposażony w specjalny chip umożliwia dokonanie wpisu wyłącznie z określonego miejsca. Jednak książki szczytowe przetrwały i są wciąż używane.

Sarah Jane Schmitt, zajmując się historią ksiąg szczytowych w Alpach, zauważa, że o ile w okresie pionierskim dokumentowanie pobytu ograniczało się do pozostawienia biletu wizytowego („elita była w swoim gronie”), o tyle w okresie rozwoju turystyki masowej wpisy stają się coraz obszerniejsze, zawierają komentarze dotyczące pogody, krajobrazu, a także własnego stanu fizycznego i psychicznego ${ }^{14}$. To zbliża księgi szczytowe do ksiąg pamiątkowych w schroniskach. Jednak ryzykowne byłoby postawienie tezy, że im trudniej dostępne miejsce, tym krótsze i wyłącznie informacyjne wpisy. W książce szczytowej wyłącznie dla wspinaczy dostępnej skały Falkenturm w Saskiej Szwajcarii (a trzeba wiedzieć, że ten zbudowany ze skał piaskowcowych rejon

10 Wegierski bądź Dacki Simplicissimus, przeł. D. Reychmanowa, przedmowa J. Reychmann, Kraków 1967, s. 11.

11 Por. J. Szaflarski, op. cit., s. 60-61.

12 Węgierski badź..., s. 112.

13 Por. B. Chwaściński, Z dziejów taternictwa. O górach i ludziach, Warszawa 1988, s. 114.

14 S.J. Schmitt, Gipfelbücher. Spuren des Dagewesenseins, „Panorama. Das Magazin des Deutschen Alpenverens" 2014, nr 1, s. 74-75. 
wspinaczkowy ze względu na trudności techniczne połączone z ograniczeniami możliwości asekuracji przyciąga elitę wspinaczy) znalazły się liczne sentencje, jak na przykład anonimowy wpis wierszem pochodzący z roku 1988, a więc jeszcze z czasów Niemieckiej Republiki Demokratycznej: „Von der Ostsee bis nach Sachsen - kein Berg ist uns gewachsen. Von Osten nach Westen — das können wir nicht testen ${ }^{15}$. W tłumaczeniu ten rymowany wpis oznacza: „Od Bałtyku po Saksonię żadna góra się nam nie oparła. Od Wschodu na Zachód — nie mamy tego jak sprawdzić”.

Można więc powiedzieć, że księgi tego gatunku stanowią pewną otwartą przestrzeń zapełnianą dość swobodnie przez autorów wpisów, a tym samym stanowią źródło wiedzy o ich mentalności, a przede wszystkim o ich mniej lub bardziej podległemu konwencjom stosunku do zwiedzanych miejsc i turystki w ogóle. Tak jest również w przypadku ksiąg ze schroniska nad Śnieżnymi Kotłami.

Podczas wstępnych kwerend obejmujących obszerny wybór wpisów do ksiąg w schronisku nad Śnieżnymi Kotłami jednym z ciekawszych aspektów okazał się bardzo nowoczesny, niejednokrotnie daleko odbiegający od postsentymentalnego i romantycznego sposobu widzenia gór, nowoczesny styl reagowania na ich piękno i górski typ przestrzeni, która wyraźnie staje się w tym okresie przestrzenią turystyki masowej. Stąd duża liczba wpisów dotyczy nie tyle piękna górskiego krajobrazu i walorów górskiej przyrody, ile ducha nowoczesności i postępu cywilizacyjnego wkraczającego na obszary górskie w ślad za intensywnym rozwojem turystyki. Liczne rysunki i wpisy rejestrują w tym okresie pojawienie się nowych schronisk (ujawniają zachwyt nad ich komfortem), przewidują w konwencji nieledwie profetycznej rozwój turystycznej infrastruktury, jawnie zapowiadają proces komercjalizacji turystyki górskiej, ukazują także nowe style zachowań (pojawienie się na szlakach kataryniarzy (sic!), początki turystyki zimowej i zimowych sportów, zwłaszcza narciarstwa, powstawanie towarzystw turystycznych i nowego typu turystyki grupowej). Ciekawie rysuje się tu także kontekst narodowo-etniczny i ekonomiczno-społeczny. Największą grupą wpisów są w tym okresie wpisy niemieckojęzyczne, rzadziej pojawiają się wpisy czeskie, w odróżnieniu od wpisów umieszczanych w Koppenbuchach w XVIII i pierwszej połowie XIX w. bardzo rzadko zdarzają się wpisy polskojęzyczne - a jeśli nawet sporadycznie się pojawiają, to są bardzo lakoniczne. Być może ma to związek z bardzo intensywnym rozwojem polskiej turystyki tatrzańskiej i programową w tym okresie turystyką w Tatry i na Podhale, co m.in. dotyczy rozpropagowania mody na Tatry przez pokolenie rówieśników Stanisława Witkiewicza.

15 www.wikipedia.org/wiki/Gipfelbuch; por. S. Hermann, Über alle Berge. Ein Handbuch nicht nur für Gipfelstürmer, München 2016. 


\section{Einige Bemerkungen über die Fremdenbücher der Schneegrubenbaude an der Jahrhundertwende}

Unter den Gedenkbüchern (Fremdenbüchern) aus dem Riesengebirge, die in den Spezialsammlungen der Breslauer Universitätsbibliothek aufbewahrt werden, verdienen zwei Korpora von dicht mit vielsprachigen Einträgen und merkwürdigen Zeichnungen gefüllten Büchern (insgesamt 21 Bände) besondere Aufmerksamkeit.

Den ersten und wertvollsten Teil der Sammlung bilden die sogenannten Koppenbücher, die Einträge aus den Jahren 1710-1840 beinhalten. Der zweite Teil, der nicht weniger interessant zu sein scheint, besteht aus einer zehnbändigen Sammlung der Fremdenbücher der Schneegrubenbaude, die in der alten und dann in der neuen Baude in den Jahren 1890-1914 ausgelegt wurden.

Diese außergewöhnlichen Dokumentensammlungen veranschaulichen die Entwicklung, sowie Veränderungen der Touristik im Riesengebirge und sollen als eine wichtige Wissensquelle über die Funktion und Bedeutung der Berge für die Kultur und für das soziale Bewusstsein angesehen werden und zwar nicht nur im regionalen, sondern auch im viel breiteren Kontext. Dank der mehrsprachigen Einträge von den Pilgern und später von den immer zahlreicheren Touristen in den so genannten Koppenbüchern (die ersten bekannten Einträge werden auf das Jahr 1696 datiert) ${ }^{1}$ kann man Schlussfolgerungen über die soziologische und national-ethnische Zugehörigkeit der Riesengebirge-Besucher vom Ende des 17. Jahrhunderts ziehen.

Dass die uns interessierenden Bücher nicht nur eine besondere Bedeutung für die Dokumentation haben, sondern im gewissen Sinne auch literarische und künstlerische Werte darstellen, bestätigt die Tatsache, dass ihre ersten gedruckten Exzerpte bereits in der ersten Hälfte des 18. Jh. entstanden. Eine Auswahl der Einträge wurde 1737 in der Druckerei Krahn in Hirschberg gedruckt und zwar unter dem barocken Titel: Vergnügte und unvergnügte Reisen auf das Weltberufene RiesenGebirge welche von 1696 bis 1737. Theils daselbst der Allerhöchsten zu preisen, theils die erstaunenden Wunder der Welt zu betrachten, theils sich eine Gemüthvergnügung oder Leibesbewegung zu machen, theils den beruffenen Riebezahl auszukundschaften, von allerhand Liebhabern angestellt worden sind. Die sich den zu einen beständigen Andenken in die daselbst befindlichen Schneekoppen - Bücher Namentlich und meistens mit beyläufigen merkwürdigen Gedanken in gebundener und ungebundener Rede eingeschrieben haben (Hirschberg 1736). ${ }^{2}$

${ }^{1}$ R. Kincel, Sarmaci na Śnieżce, Wrocław 1973, S. 7.

2 Zit. nach: J. Kolbuszewski, Vergnügte und Unvergnügte Reisen auf das weltberufene schlesische Riesengebirge, [in:] Daß eine Nation die ander verstehen möge... Festschrift für Marian Szyrocki zu seinem 60. Geburtstag, herausggeben von N. Honsza und H.-G. Roloff, Amsterdam 1988, S. 438. 
Weitere Einträge aus den Koppenbüchern erschienen Ende des 18. Jh. im Druck. Laut Ryszard Kincel erschien

Am Ende des 18. Jh. [...] eine die Einträge aus den Koppenbüchern aus den Jahren 1774-1789 präsentierende Publikation. Ein ähnliches Exzerpt wurde noch im Jahre 1769 herausgegeben. Zugleich füllten sich aber immer neue Bände mit Gedenkbüchern mit Einträgen. Eine wahre Mode für solche Einträge entwickelte sich aber erst in der ersten Hälfte des 19. Jh. Als diese Sitte in der zweiten Hälfte des 19. Jh. immer seltener wurde, hat sie das Interesse der Heimatkundler erweckt, die allerdings nicht feststellen konnten, was mit den Büchern passiert ist. Die Originale der Bücher, die früher den Touristen in der Hütte, sowie in der Kapelle auf der Schneekoppe dienten, konnten einfach nirgends gefunden werden. Am Ende des vorigen Jahrhunderts wurden in Bunzlau doch zwei Bände von originalen Koppenbüchern gefunden um dann in die Sammlungen des Museums in Hirschberg zu gelangen. Das erste Buch umfasste die Jahre 1800-1806, das zweite dagegen die Jahre 1812-1819. Eine Charakteristik der beiden Bücher, die ihren Wert als Quelle des Wissens über die Geschichte der Bergtouristik hervorhebt, wurde 1886 in einer heimatkundlichen Zeitschrift publiziert, deren Titel in der polnischen Übersetzung „Wędrownik w Karkonoszach“ lautet ${ }^{3}$ [Originaltitel der Zeitschrift: „Der Wanderer im Riesengebirge“ 1881-1943].

Nach dem Zweiten Weltkrieg hat es sich herausgestellt, dass in der Breslauer Universitätsbibliothek eine umfangreiche Sammlung dieser Bücher erhalten geblieben ist. Überraschenderweise haben die im guten Zustand erhaltenen Fremdenbücher aus dem Riesengebirge trotz ihres dokumentarischen Wertes in der zweiten Hälfte des 20. Jh. nur geringes Forschungsinteresse geweckt und wurden nur im gewissen Umfang kommentiert. Eine Hürde für die Forscher stellten vielleicht die ungünstigen politischen und ideologischen Zusammenhänge jener Zeit dar. In diesem Kontext soll auf Pionierarbeiten von Jacek Kolbuszewski hingewiesen werden, der nicht nur die polnischsprachigen Einträge - auf die sich Ryszard Kincel als Autor der wertvollen Arbeit Sarmaci na Śnieżce (1973) konzentrierte, sondern auch die deutschsprachigen und tschechischsprachigen untersuchte ${ }^{4}$, sowie auf den den deutschsprachigen Einträgen gewidmeten Beitrag von Kettelsen. ${ }^{5}$

${ }^{3}$ R. Kincel, Sarmaci na Śnieżce, Wrocław 1973, S. 8.

4 J. Kolbuszewski, Czeskie wiersze w księgach pamiątkowych Śnieżki, „Sbornik Praci Filozoficke Fakulty Brnenske Univerzity Studia Minora Facultatis Philosophicae Universitatis Brunensis" 1985, Bd. 32, S. 131.

${ }^{5}$ Uwe-K. Ketelsen, Ein Einbruch der Ungelehrten in die Domäne der Schrift. Touristische Konstituierung von Natur im „Koppen-Buch” des Grafen Schaffgotsch, [in:] Aufklärung in Schlesien im europäischen Spannungsfeld Traditionen-Diskurse-Wirkungen, Hrsg. W. Kunicki, Wrocław 1996, S. 111-131. 
Das Interesse der Forscher weckten dabei nur die Koppenbücher, die die ältesten Einträge beinhalten, seltener griffen sie nach den Fremdenbüchern der Schneegrubenbaude aus der Jahrhundertwende.

Der bis jetzt kein Forschungsinteresse weckender Korpus der Fremdenbücher der Schneegrubenbaude scheint dabei besonders interessant zu sein, da er ein wichtiges Dokument des Reisestils, aber auch der Veränderungen im Prozess der Perzeption des Gebirgsraumes an der Wende des 19. zum 20. Jh. darstellt, ein Dokument, das die spektakulären Veränderungen des sozialen und kulturellen Bewusstseins der Riesengebirgebesucher jener Zeit verfolgen und rekonstruieren lässt. Es scheint, dass es universelle Erscheinungen und Tatsachen sind, die man mit breit verstandenen Erscheinungen in Europa vergleichen kann.

Bereits eine erste Analyse von den ersten Bänden der Fremdenbücher der Schneegrubenbaude weist auf die sich in jener Zeit deutlich abzeichnenden Anfänge der Massentouristik ${ }^{6}$, einer Touristik, die intensiven Demokratisierungsprozessen unterliegt und deutlich modernistisch geprägt ist.

Die uns interessierenden Fremdenbücher der Schneegrubenbaude im Riesengebirge gehören zu einer sich intensiv in der ersten Hälfte des 19. Jh. entwickelnden und an der Wende des 19. und 20. Jh. weiter funktionierenden Gattung. In Anlehnung an die Anfänge der Koppenbücher im 17. Jh. könnte man nach einer genetischen Verwandtschaft mit dem Modell des adeligen Silva rerum suchen. Darauf hat seiner Zeit Jacek Kolbuszewski hingewiesen. ${ }^{7}$

Das Konzept der Koppenbücher, sowie der Fremdenbücher der Schneegrubenbaude sollte nicht mit den heutigen Hüttenbüchern verwechselt werden. Die Hüttenbücher, in denen Besteigungspläne, Abmarschzeiten, sowie die Zeiten der geplanten und faktischen Rückkehr dokumentiert werden, dienen der Sicherheit und teilweise der äußeren Dokumentation.

Die Funktion der hier besprochenen Fremdenbücher ist es, den Aufenthalt auf der Baude oder im Gebirge zu verewigen. Man sollte hier also eher nach einer direkten Verwandtschaft mit den an touristisch attraktiven Orten wie Baudenkmäler, Kurhäuser, Gedenkstuben ausgelegten Gedenkbüchern suchen und andererseits mit den Gipfelbüchern, die in der ersten Reihe dem Dokumentieren der Anwesenheit auf einem (oft schwer zugänglichen) Gipfel, dienen.

Es scheint, dass es das Bedürfnis ist, seine Anwesenheit an einem von der Perspektive des Autors außergewöhnlichem Ort zu dokumentieren, was dieser Gattung zugrunde liegt. In diesem Kontext könnten wir ihre Anfänge mit dem Phänomen der Felseninschriften verbinden, wie die, von deren Entstehung Jakob Buchholtz in seinem Bericht über den Ausflug zum Lomnitzer See in der Tatra schreibt. Dort sei sein älterer Bruder Georg „,im Anfall einer Leichtsinnigkeit“" bis zur Mitte des Sees geschwommen und habe auf einem daraus ragenden Felsen

${ }^{6}$ Für das die Erscheinung der Massentouristik initiierende Datum wird das Jahr 1841 gehalten und für seinen Schöpfer der Brite Thomas Cook, der am 5. Juli 1841 einen Zug gemietet und eine Exkursion zum Temperenztreffen von Leicaster nach Loughborough und zurück organisiert.

7 J. Kolbuszewski, Vergnügte und Unvergnügte Reisen..., S. 437. 
„mit dem Messer seinen Namen geschnitzt ${ }^{“ .} .{ }^{8}$ Solche Inschriften entstanden auf eine spontane Art und Weise. Das Hinterlassen von Visitenkarten in den Gipfelbüchsen war dagegen mit gewisser Planung als Punkt im Ausflugsprogramm verbunden. Darüber lesen wir bereits in dem 1683 erschienenen ${ }^{9}$ Schelmenroman „Ungarischer oder Dacianischer Simplicissimus“, wobei die dort beschriebene Gipfelbesteigung wahrscheinlich um das Jahr 1650 stattfand und auf die Kesmarker Spitze führte: ${ }^{10}$

Der Wegweiser zeigte uns unter einem herabhengenden abscheulichen Felsen etlich über einen Haufen getragene Stein/unter welchen blechene Schächtelein/und in solchen auf Pergament geschriebene Namen waren; Uns reuete/daß wir nit auch zum Gedächtnis dergleichen mitgenomen: der Wegweiser sagte/ich habe Pergament un ein blechen Schächtlein/was gebt ihr mir darum/wann ich euch solches/und dazu Feder und Dinten gebe?wir botten ihm $1 \mathrm{fl}$. Das musten wir ihm versprechen zu halten/also schrieb ein jeder seinen Namen/Alter/Geburtsstadt/Jahr und Tag/legtens ins Schächtlein/und trugen wieder Steine/mehr als zuvor darauf ${ }^{11}$.

Die Sitte, solche Informationen über die Besteigung eines Gipfels, darauf zu hinterlassen, gewann während der Erschließung in den Alpen und anderen Gebirgszügen an einer besonderen Bedeutung. Unter den Bergsteigern in der Tatra wurde der Streit zwischen Roman Kordys und Karol Englisch bekannt, der unter anderem die Erstbesteigung der Westlichen Gabelspitze betraf. Über den Streit entschied Miklos Szontagh der Jüngere, indem er berichtete, dass er auf dem Gipfel die Visitenkarte von Englisch gefunden hat. ${ }^{12}$ Heute sind bei solchen Entscheidungen die Gipfelaufnahmen behilflich. Immer bekannter wird das digitale System, das auf einem in das GPS-Gerät eingebauten und den Eintrag nur von einem konkreten Ort ermöglichenden Chip, basiert. Doch die Gipfelbücher werden weiterhin benutzt.

Indem sich Sarah Jane Schmitt mit der Geschichte der Gipfelbücher in den Alpen beschäftigt, bemerkt sie, dass sich das Dokumentieren der Besteigung in der Pionierzeit auf das Hinterlassen der Visitenkarte beschränkte (,die Elite war unter sich"). Erst mit der Entwicklung der Massentouristik werden die Einträge immer umfangreicher, enthalten Kommentare über das Wetter, die Landschaft, sowie über die eigene psychische und physische Auffassung. ${ }^{13}$ Das bringt die Gipfelbücher in die Nähe der Gedenkbücher aus den Hütten. Doch die These, dass je schwerer zugänglich der Ort, desto wortkarger der Eintrag, scheint uns zu wage. So kann man im Gipfelbuch des nur Kletterern zugänglichen Falkenturms in der

8 Zit. nach: J. Szaflarski, Poznanie Tatr, Warszawa 1972, S. 129.

9 D. Speer, Ungarischer oder Dacianischer Simplicissimus, 1648, S. 87.

10 Vgl. J. Szaflarski, Poznanie Tatr..., S. 60-61.

11 D. Speer, op. cit., S. 112.

12 B. Chwaściński, Z dziejów taternictwa. O górach i ludziach, Warszawa 1988, S. 114.

13 S.J. Schmitt, Gipfelbücher. Spuren des Dagewesenseins, [in:] „Panorama. Das Magazin des Deutschen Alpenvereins“, 1/2014, S. 74-75. 
Sächsischen Schweiz (es sei dabei zu bemerken, dass dieses aus Sandsteinfelsen gebaute Klettergebiet wegen seiner technischen Schwierigkeiten und begrenzten Sicherungsmöglichkeiten nur die Kletterelite anzieht) zahlreiche Sentenzen finden, wie z.B. der anonyme gereimte Eintrag, der noch aus der DDR-Zeit (1988) stammt: „Von der Ostsee bis nach Sachsen - kein Berg ist uns gewachsen. Von Osten nach Westen - das können wir nicht testen".14

Man kann also feststellen, dass die Bücher dieser breiten Gattung einen offenen Raum darstellen, der relativ frei von den Autoren der Einträge gefüllt wird. So stellen sie eine Quelle des Wissens über die Mentalität und vor allem über das mehr oder weniger mit den Konventionen zusammenhängende Verhältnis zu den besichtigten Orten und zu der Touristik. So ist es auch im Falle der Fremdenbücher der Schneegrubenbaude.

Während der ersten Recherche, die eine umfangreiche Auswahl von Einträgen in die Fremdenbücher der Schneegrubenbaude umfasste, fiel als ein interessanter Forschungsaspekt eine von der postsentimentalen und romantischen abweichende moderne Betrachtungsweise, sowie die moderne Art, auf die Schönheit der Berge und den gerade zum Raum der Massentouristik werdenden Gebirgsraum zu reagieren. Daher betreffen viele der Einträge nicht nur die Schönheit der Berglandschaft und -natur, sondern den modernen Geist der Zivilisation und des Fortschritts, der der intensiven touristischen Entwicklung folgt. Zahlreiche Zeichnungen, sowie enthusiastische Einträge registrieren z.B. das Auftauchen von neuen Hütten und geben der Bewunderung für ihren Komfort Ausdruck), sie zeigen in einer fast prophetischen Konvention die Entwicklung der touristischen Infrastruktur, kündigen den Kommerzialisierungsprozess der Bergtouristik an, zeigen neue Verhaltensweisen (z.B. das Auftauchen von Drehorgelspielern (sic!) auf den touristischen Wegen, Anfänge der Wintertouristik und des Wintersports, insbesondere des Skisports, die Entstehung von touristischen Verbänden, sowie Entwicklung der Gruppentouristik). Was die Nationalität der Gäste, sowie auch die ökonomisch-soziale Perspektive betrifft, liefern die Fremdenbücher der Schneegrubenbaude auch interessante Informationen. So bilden die deutschsprachigen Einträge die größte Gruppe, wobei die tschechischen seltener sind. Im Unterschied zu den Einträgen in den Koppenbüchern im 18. und in der ersten Hälfte des 19. Jh. sind die polnischsprachigen Einträge sehr selten und dann eher wortkarg. Vielleicht hängt das mit der intensiven und programmatischen Entwicklung der Tatratouristik zu jener Zeit zusammen, was wiederum mit der Verbreitung der Popularität der Tatra durch die Generation von Stanisław Witkiewicz zu tun hatte.

${ }^{14}$ Zit. nach: www.wikipedia.org/wiki/Gipfelbuch, vgl. auch Sebastian Hermann, Über alle Berge. Ein Handbuch nicht nur für Gipfelstürmer, München 2016. 